\title{
Oropharyngeal Cancer Pathologic Distant Metastasis TNM Finding v7
}

National Cancer Institute

\section{Source}

National Cancer Institute. Oropharyngeal Cancer Pathologic Distant Metastasis TNM

Finding v7. NCI Thesaurus. Code C89016.

A pathologic finding about one or more characteristics of oropharyngeal cancer,

following the rules of the TNM AJCC V7 classification system as they pertain to distant metastases. There is no pathologic M0 for oropharyngeal cancer. 